\title{
BIOWASTE RECYCLING TECHNOLOGIES IN LATVIA
}

\author{
Kristina Mežapuke $e^{I}$ \\ Rute Bendere ${ }^{I}$ \\ Dz. Zarina ${ }^{2}$ \\ L. Dubova ${ }^{2}$ \\ ${ }^{I}$ Waste Management Association of Latvia, Latvia \\ ${ }^{2}$ University of Latvia, Latvia
}

\begin{abstract}
Protection of environment is a worldwide problem. Generation of organic waste is increasing and strategies for its environmentally sound use must be developed and optimised. Accumulation of great quantities of organic wastes leads to the serious environmental problems: polluted water, contaminated soils, polluted air and solid wastes. Waste water treatment plants produce in large quantities sewage sludge. Among the different types of municipal organic wastes sewage sludge is the main product.

Waste Management plan for Latvia sets that disposed biodegradable waste amount till 2010 must not exceed $75 \%$ from the biodegradable waste amount disposed in 1995. Proposal for the Strategy on biodegradable waste management were elaborated by Waste Management Association of Latvia (WMAL), and in collaboration with Institute of Microbiology and Biotechnology, University of Latvia an approbation of organic municipal waste composting technologies is performed in the frames of LIFE - ENVIRONMENT program project in Riga district.
\end{abstract}

\section{KEYWORDS}

Municipal and industrial waste; Composting technologies; Microorganisms

\section{INTRODUCTION}

The treatment of the biodegradable waste is an actual question in various European countries int. al. in Latvia. The predicted amount of household waste per inhabitant in Latvia [1] and biodegradable waste percentage in it for next decades compared with the same parameters for several European countries are presented in Figures 1 and 2. Elaborated forecast for produced waste amount shows that household waste as well the biodegradable waste amount will increase.

As it is shown on the Figure 1, the household waste amount generated by inhabitants in Latvia during the period of $1995-2001$ were less then in the selected countries, but the waste grow tendencies are similar as in other European countries. Figure 2 shows that 


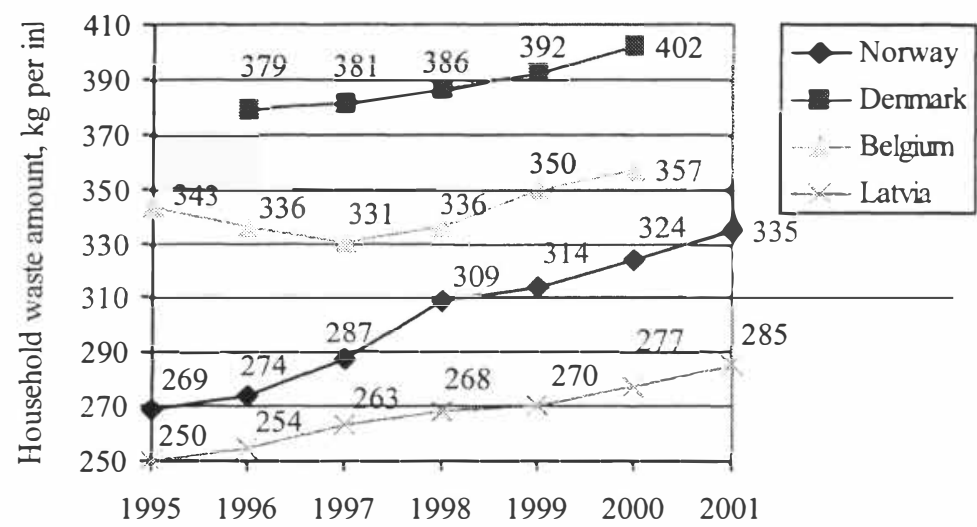

Figure 1. Changes of household waste amount in European countries and in Latvia in period $1995-2001[1,2,3]$.

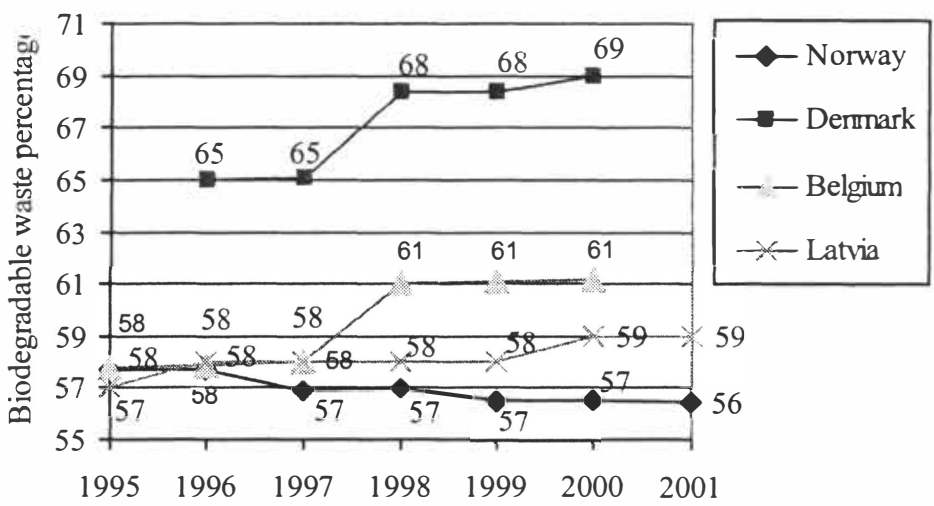

Figure 2. Percentage changes of biodegradable waste part in European countries and in Latvia in period $1995-2001[1,2,3]$.

biodegradable waste percentage in the household waste is like in Latvia, Belgium and Norway.

It was stated that an average biodegradable waste amount in Latvia in 1995 was 488000 tones, which set approximately $53 \%$ of total municipal (from households and industry) waste. So, according to the State waste management plan [4] the treated biowaste amount must increase till 122000 tones per year in 2010. To promote the implementation of this task, we 
need to elaborate biotechnologies for rapid and high quality composting for separately sorted and collected biodegradable waste streams. The biodegradable treatment technologies were compared from economical, technical and environmental point. It was acknowledged that as the best for the Latvian circumstance is an aerobic composting.

Composting is a biological process, converting organic matter in the presence of suitable amounts of air and moisture into humus-like product, in which the microbial activity is essential for the decomposition and bio-oxidation of organic materials. Waste materials can be stabilized before deposition by aerobic degradation processes to reduce the biodegradable organic material.

Composting of municipal wastes may follow two main purposes:

(1) decreasing the reactivity of municipal wastes or waste fractions before deposition in sanitary landfills or

(2) preparation of soil conditioner or a natural fertilizer from plant materials and biowastes fractions.

Feedstock can be characterized by chemical, physical and biological parameters including moisture content, particle size, organic matter content, nutrient content, heavy metal content, and synthetic content.

The aim of this work was specifying of composting conditions for different types of waste and evaluation of the quality of the final product.

\section{MATERIALS AND METHODS}

Composting processes were realized in a solid state bioreactor (volume $3 \mathrm{~L}$ ) and in a composting Bin (Biolan Juwel BIO) (volume $600 \mathrm{~L}$ ). In field conditions, the composting processes were carried out in a windrow. A windrow was $2-3 \mathrm{~m}$ in height, $3 \mathrm{~m}$ in width and $12 \mathrm{~m}$ in length. During the first two months in a windrow and one month in a bioreactor, the composting process was realized under anaerobic conditions; then it was continued under aerobic conditions, while the composting process in a Bin was realized under facultative anaerobic conditions.

For the improvement of the composting process two Trichoderma strains: Tr. viride and Tr. lignorum, as well as nitrification association, which regulates the circulation of nitrogen ammonification and nitrification processes, were applied.

The material for composting was prepared as follows: domestic organic waste with sawdust and inoculum was prepared, i.e. mixed and humidified out of a bioreactor, a Bin and windrow. Place the raw materials in layers using balance to high carbon (moist) and low carbon (dry) materials. Each layer should be no more than 10 to $15 \mathrm{~cm}$ in depth. Spray each layer with inoculum.

Procedure:

Step 1. Start a 10 to $15 \mathrm{~cm}$ layer of coarse material set on bottom of the composter or on top of the soil.

Step 2. Add a 7 to $10 \mathrm{~cm}$ layer of low carbon material.

Step 3. Add a 10 to $15 \mathrm{~cm}$ layer of high carbon material.

Step 4. Add a $2.5 \mathrm{~cm}$ layer of garden soil or finish compost, or inoculum of microorganisms.

Step 5. Mix the layers of high carbon material, low carbon material, and soil or compost, or inoculum. 
Repeat steps 2 through 5 until the bioreactor and bin is filled and windrow reached $3 \mathrm{~m}$. New materials should be added to the composting system during tuming or mixing.

General physical - chemical characteristics of compost were determined: moisture, $\mathrm{pH}$, organic carbon, total nitrogen, $\mathrm{C}: \mathrm{N}$ ratio etc [5]. The quantification of the total number of microorganisms, fungi, Escherichia coli and Salmonella sp. in the compost was performed. The quality of manure composts has been determined using the seed germination tests (cress salad, tomato and cucumber). Besides, plants were cultivated in compost, and the quality of plants properties was characterized as follows: biomass, length and the content of different pigments in leaves [6].

\section{RESULTS}

The quality of compost was characterized by $\mathrm{pH}$, moisture, total $\mathrm{C}$ and $\mathrm{N}, \mathrm{C}: \mathrm{N}$ ratio, determined by biological tests and microbiological analyses. Figure 3 shows the change of the parameters of compost during the composting process for used technologies.

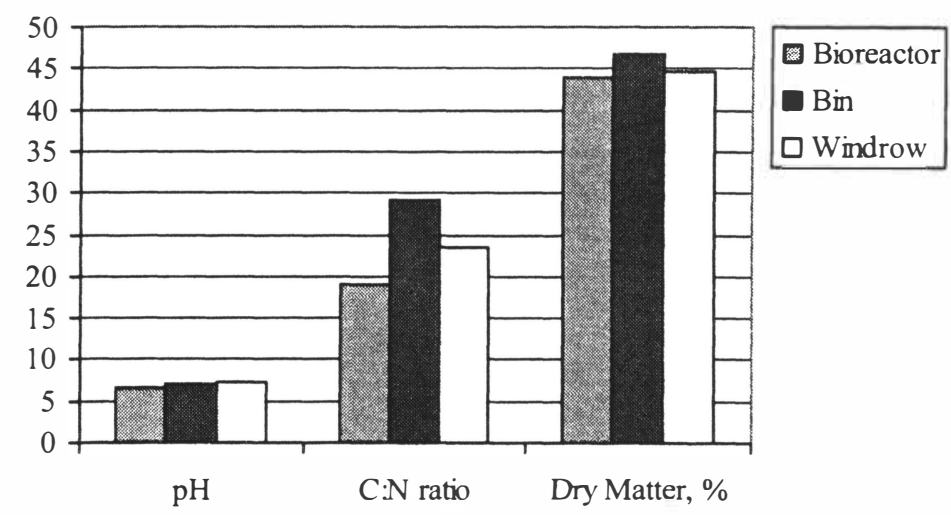

Figure 3. Parameters of compost for different technologies 
Table 1. Comparison of different organic waste composting technologies (the amount of microorganisms in compost)

\begin{tabular}{|c|c|c|c|c|}
\hline \multirow[b]{2}{*}{$\frac{\mathfrak{a}}{\grave{\Xi}}$} & \multicolumn{4}{|c|}{$\begin{array}{c}\text { Number of bacteria } \\
\text { (cells per } 1 \mathrm{~g} \text { dry compost) }\end{array}$} \\
\hline & 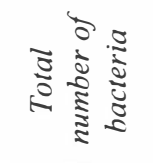 & 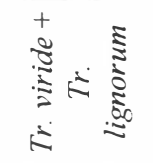 & 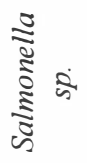 & 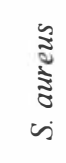 \\
\hline Bioreactor & $4.56 \times 10^{6}$ & $1.33 \times 10^{4}$ & 0 & - \\
\hline Bin & $4.21 \times 10^{6}$ & $5.2 \times 0^{3}$ & 0 & 290 \\
\hline Windrow & $1.04 \times 10^{7}$ & $2.35 \times 10^{3}$ & 0 & 360 \\
\hline
\end{tabular}

Table 2. Compost quality (biological tests with cress salad) during the composting process in the windrow

\begin{tabular}{cccc}
\hline \multirow{2}{*}{ Date } & \multicolumn{3}{c}{ Seeds germination tests } \\
\cline { 2 - 4 } & \multirow{2}{*}{ Germination, $\%$} & Roots length (average) \\
\cline { 3 - 4 } & & $\mathrm{mm}$ & $\%$ of control \\
\hline 10.03 .04 & 100 & 15.78 & 33.13 \\
\hline 22.03 .04 & 100 & 18.10 & 38.00 \\
\hline 31.03 .04 & 100 & 20.66 & 54.58 \\
\hline 14.04 .04 & & 19.50 & 40.94 \\
\hline
\end{tabular}

Figure 3 and Table 1 show that the most qualitative compost from household waste was obtained in a bioreactor. The compost can be used in gardens and fields, because it can provide valuable nutrients and organic matter to soil. However, the compost obtained either from a Bin or a windrow contained Staphylococcus aureus. Therefore, this material is applicable only for waste dump recultivation.

During composting a more significant decrease in the compost toxicity level was determined with Toxkit microbiotests. Seeds germination tests did not show any toxic effects (see Table 2, Figures 4 and 5). 


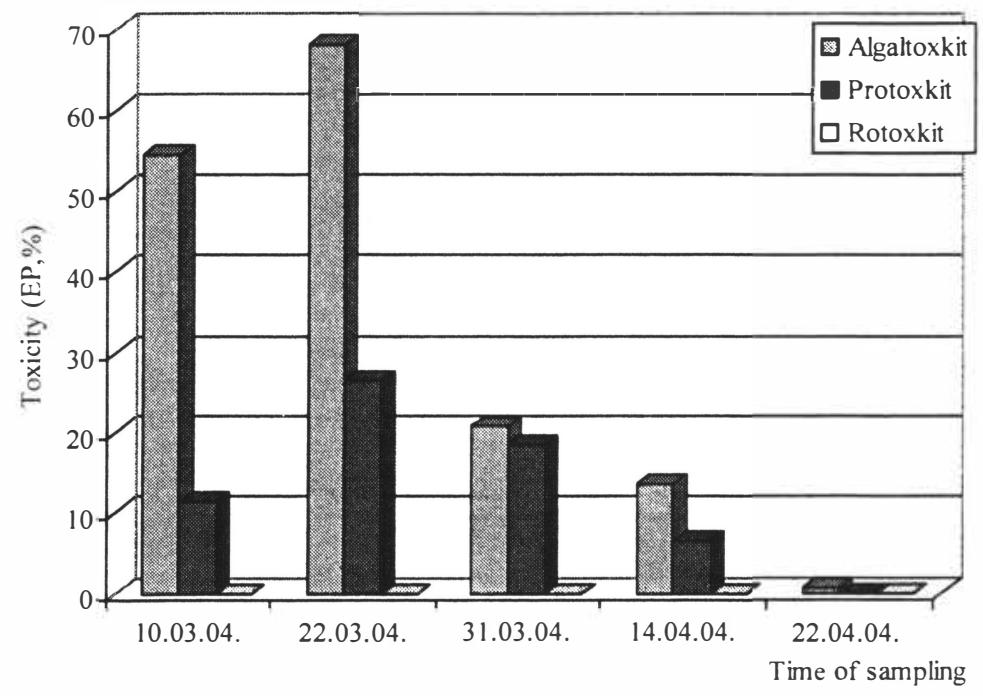

Figure 4. The compost quality (toxicity) during composting process in the windrow

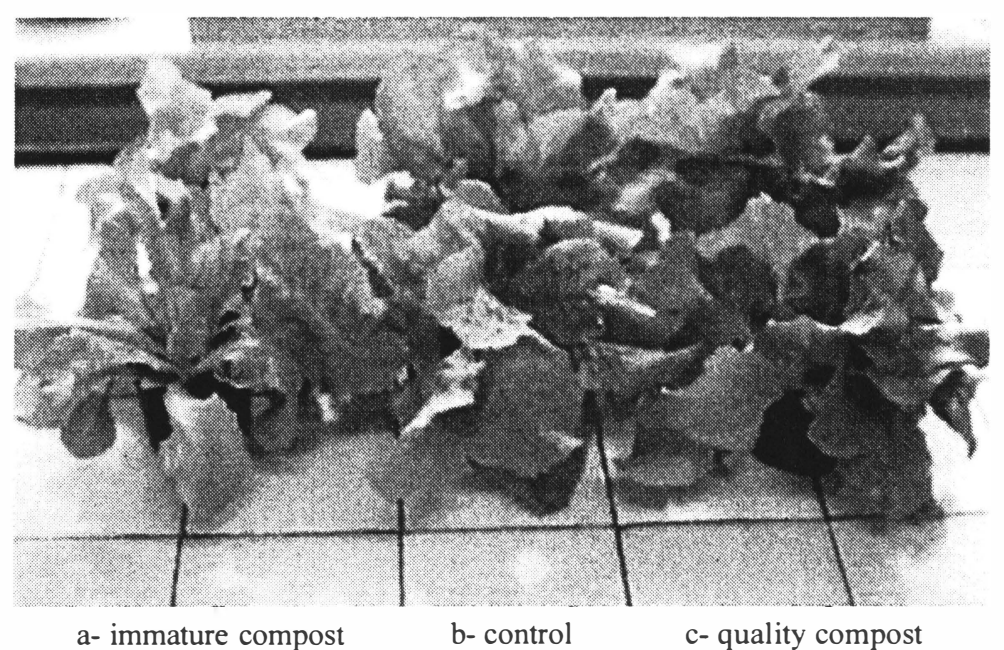

Figure 5. Cressalad (Lepidum sativum L.) cultivation on the peat (control) and immature, and quality compost 
Table 3. Price of 1 ton of compost material using different technologies

\begin{tabular}{lcc}
\hline Composting technologies & \multicolumn{2}{c}{ Costs pertt (relative units $)$} \\
\cline { 2 - 3 } & $\begin{array}{c}\text { Small facility } \\
(4400 \mathrm{t} / \text { year })\end{array}$ & $\begin{array}{c}\text { Big facility } \\
(11000 \text { t/year })\end{array}$ \\
\hline Open air technology & 12 & 11 \\
\hline Composting using bioreactor & 20 & 12 \\
\hline Windrow technology & 11 & 12 \\
\hline Composting using plastics sacks & 13 & 7 \\
\hline
\end{tabular}

On this basis two types of biowaste treatment schema were revised - the development of many small composting facilities ( $\sim 4000$ tones annually), or to organize one big composting facility in the region with 200000 inhabitants were can be treated $\sim 11000$ tones of biowaste annually. The Table 3 shows the calculated expenses for one ton of produced bio compost with different methods.

In the frame of provided project can be stated: to obtain the compost of a good quality, the composting material needs to be treated under thermophylic conditions in bioreactor, and afterwards - placed in windrow to continue the process. Aeration in windrows should be provided by intensive mixing. Moisture content in windrows can be maintained by additional moistening, if necessary.

\section{CONCLUSIONS}

- Performed chemical and microbiological analyses demonstrated that the high quality compost is obtained by waste treatment in bioreactor.

- The high quality compost is without sawdust particles and nuisance of odor, no toxic compounds were detected with used microbiotests.

- Compost of lower quality may be used for the remediation of old dumpsites.

- During the work was established that the optimization of the characteristics of waste mass and the reduction of the concentration of possible toxic impurities are important factors for the successful composting process.

\section{REFERENCES}

[1] “Priekšlikumi stratēgijai par biolog̣iski noārdāmo atkritumu apsaimniekošanu atbilstoši Eiropas Padomes direktīvas 1999/31/EC par atkritumu apglabāšanu un Ministru kabineta 2002. gada 3. janvāra noteikumu Nr. 15 prasībām” („Proposals for the Strategy on Biodegradable Waste Management in accordance with the Requirements of Europe Council Directive 1999/31/EC on Waste Disposal and Requirements of Regulations issued by the Cabinet of Ministers Nr.15 (03.01.2002)"), pp. 14-20 (in Latvian).

[2] Statistics Norway, Household waste, 2002, http://www.ssb.no

[3] Indicator Fact Sheet Signals 2001, European Environmental Agency, http://themes.eea.eu.int

[4] Waste management plan for Latvia 2003-2010, http://vidm.gov.lv 
[5] Viesturs, U., Zarina, Dz., Strikauska, S., Dubova, L., Bērzinš, A., 2004. Solid State Fermentation Systems for Bioremediation and Biodegradation. LLU Raksti, 12 (307), $1-8$.

[6] Dubova, L., Zarina, Dz., 2004.. Application of Toxkit Microbiotests for Toxicity Assessment in Soil and Compost, Environmental Toxicology, Australia 19, 274-279. 